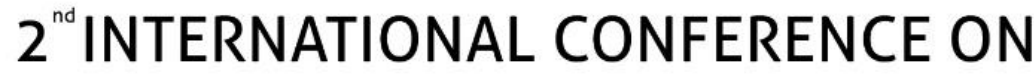 FUTURE OF TEACHING \& EDUCATION
}

Munich,Germany

6 - 8 December,2019

\section{Reward and Punishment System Applied to Students in Military Educational Institutions in the Ottoman Empire: the Example of Military Secondary School}

\author{
PATOGLU, Emrah Berkant ${ }^{1}$, DOGAN, Ayhan ${ }^{2}$ \\ ${ }^{1,2}$ Assistant Professor, Gaziantep University, Faculty of Education, Department of Educational Sciences, \\ Philosophical and Historical Foundations of Social Department of Education, Gaziantep / Turkey
}

\begin{abstract}
The first steps of innovation, which emerged due to the decline of the Ottoman Empire, were taken in the field of education. The most important part of modernization in education, which gained high speed, especially in the Tanzimat (Reorganization) reform period, was the military educational institutions. After schools such as military high schools and secondary schools were established, the modernization practices in education continued at a fast pace. It began in engineering schools at the end of the XVIII century, a long-time after the opening of military high schools in 1845, as a result of a decision taken on January 9, 1875, military secondary schools were opened to meet the students' need of military high schools. This study aims to reveal the rules (rewards and punishments) established to regulate the behaviours of military secondary school students through the historical document analysis method.Case studies have been benefited from in this research, which was conducted through qualitative research methods and techniques. As a result of the archive and literature screening, the management and institutional functioning of the military secondary schools were determined by the directives published in specific periods. The resources of the research are library data, especially archival documents, including legal regulations. The findings obtained from those resources have been enriched by memoirs and inferences have been made accordingly.
\end{abstract}

Keywords: History of Turkish Education, Military Secondary School, Reward and Punishment in Education, Education in the Ottoman Empire

\section{Introduction}

Military secondary schools are the institutions established in the last quarter of the XIX. century in the Ottoman Empire, which constitute the first step of military education. First opened in 1875 during the reign of Sultan Abdulaziz with the efforts of Suleyman Husnu Pasha, the Minister of Military Schools of that period, also known as the "Hero of Shipka," these schools spread in almost every region ruled by the Ottoman Empire during the reign of Sultan Abdul Hamid II. These schools, which are opened with the efforts of the military school's minister Suleyman Hosni Pasha, also known as the "Hero of the Shipka" are significant. They are significant because many essential names in the founding and executive staff of the Republic 


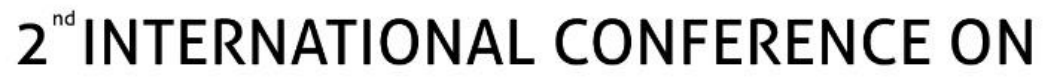 FUTURE OF TEACHING \& EDUCATION
}

\section{Munich,Germany}

\author{
6 - 8 December,2019
}

of Turkey have graduated from these schools. The starting point of this research has been that there has been no independent study conducted about the disciplinary rules of these schools ${ }^{1}$.

This study covers the period between the establishment and closure of the military secondary schools (1875-1913), dealing with the disciplinary rules applied to the students receiving education in the military sections thereof. Accordingly, the original historical information regarding the rules about the behaviours and assessment of students have been revealed, and some evaluations on the data obtained were carried out.

The rules governing the institutional functioning of military secondary schools were determined by the instructions issued periodically. It has been seen that those instructions were the same in general terms, but some had minor differences. For example, the directive dated May 6,1905, covered all students while the one dated May 26, 1906, had some articles distinguishing "the students in the Center (Istanbul) and those in the country." In addition to the guidelines published in relation to the rules that students must comply within and outside the school, the application of intermediate exams and end-of-term exams, the rules that must be followed by the students who fail the course, and also the attitude and morality instructions were also published. Those instructions were distributed to all students.

This study, which obtained its data from archival documents, memoirs, and researches, aims to seek an answer to the following questions:

- What are the disciplinary rules in military secondary schools and to what extent are they followed?

- What are the rewards and punishments given to students at military secondary schools?

\section{Methods}

This study, made using qualitative research methods and techniques, has been conducted through case studies. In this context, the research has been trained in military secondary schools, as well as documents obtained from the Ottoman archives of the presidency of the State Archives of the Republic of Turkey and various libraries from the Ottomans collection of works. With the memories of people. The findings obtained from these documents, including the management and institutional functioning of such schools, were simplified by transcribed into today's Turkish alphabet and supported by memorization and auditing works, and detailed assessments have been made.

\footnotetext{
${ }^{1}$ Concerning to the topic "Training and instruction in the military secondary education institutions in the second legitimacy process" the study mentions awards and penalties for military schools in the Ottoman Empire. However, military secondary schools are detached and not discussed in detail. See: Ozbey, 1999.
} 


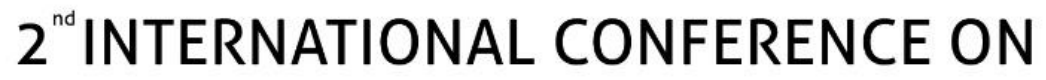 FUTURE OF TEACHING \& EDUCATION
}

Munich,Germany

\author{
6 - 8 December,2019
}

\section{Results and Discussion}

According to the Turkish Language Society's dictionary, the word "reward" means "a gift or prize given in exchange for good behaviour or success." The same dictionary gives the meaning of the word "punishment" as "a saddening, distressing or agonizing action or sanctions applied to those behaving improperly." (TDK, 2019). The evaluation of the main problem focused on in this study has been performed through two themes based on these two concepts:

- The reward system applied to students at military secondary schools

- The punishment system applied to students at military secondary schools

The standard and central point of these analysis themes, created by document reviewing, is the student. These themes and their content in the context of research are presented in the following sections as sub-headings.

\subsection{The Reward System at Military Secondary Schools}

It has been determined that the prizes to be given to the students under the title of moral record are defined in the instructions published for military secondary schools. Accordingly:

"There are four rewards that students will attain: "praising, liking, commending, gratifying (rewarding)" and four praisings equal to a liking, three likings equal to a commending, and two commendings equal to a gratifying (OHN, May 1906, p. 60)."

The rewards to be given to students are built upon a four-step structure. When any of the subelements is repeated for a certain number of times, it equals to the next reward. Therefore, cross relations between rewards were established in this four-step structure. The exchange between different reward levels is as follows:

"Four praising letters given to students according to their lessons, attitudes, and morality are exchanged with one liking letter, three liking letters with one commending letter and two commending letters with one gratifying letter and the documents taken back are written "exchanged" with indelible ink by the school principal and sealed with the seal of the school and given back to the students. The reward documents, which are not canceled and retained by the students, preserve their value in the military secondary schools in the following year. The materials that the students will give are torn in response to the penalties (OHN, May 1906, p. 60)."

As can be seen, the conversion from praising to liking, liking to commending, and commending to gratifying was considered to be a task performed by the school principals. It was decided to write explanations with a permanent ink pen on the documents taken back once completed. It is understood that some rewards are used in response to punishments in this process, which is meticulously explained. However, it is necessary to answer a question before dealing with this point. Are these rewards obtained displayed in any way? The relevant article gives the following explanations related to this point:

"Students who collect two reward letters, one for morality and one for lessons, shall wear a yellow silk ribbon that is fifteen centimeters long and one centimeter wide on the upper side of 


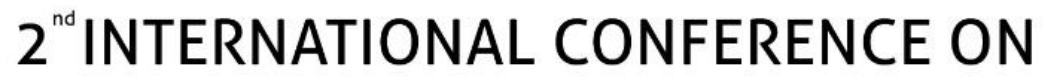 FUTURE OF TEACHING \& EDUCATION
}

Munich,Germany

\author{
6 - 8 December,2019
}

the grade ribbons of their right arm. Per the general director (the high school principal in the country schools and the principal himself in regions where there is no high school). When these students have three ribbons and are entitled to receive a fourth ribbon, they remove the silk ribbons and wear a yellow golden ribbon in the same dimensions which are equal to the four ribbons by order of the general director. They shall stitch the silk ribbons they will be entitled to on the underside of the golden ribbon so that the number of the golden ribbons will increase as the silk ribbons are changed (OHN, May 1906, p. 61)."

As can be seen from the above explanations, students are encouraged to exhibit positive behaviors through the display of their rewards. Therefore, being entitled to these kinds of rewards can be said to become a source of prestige in the eyes of students when the issue is evaluated in terms of social psychology. At this point, the question of which particular behaviors will result in such rewards appears as a question to be answered. It seems that many explanations are made in this respect in the article below:

"Students who continue with the school uninterruptedly and those behaving mannerly shall be entitled to receive a letter of praising if deemed suitable by the officers in charge and approved by the principal. Students achieving success in their courses during the school year shall be given a letter of praising by the school principal upon the approval of their teachers. These students will be given a praising for each time they get a full score in the midterms. In addition, if they get a full score in all courses, they shall be given a letter of praising and a letter of liking at most. Apart from the rewards for behavior and morality stated in the previous article, if the level of any course is extraordinarily good, it shall be sent to the ministry with the certificate in order to be granted the "letter of liking" shown in the relevant copy (OHN, May 1906, p. 6162)."

When the explanations above are scrutinized, it can be said that what the specific behaviors required to win rewards are not defined clearly and depend on the abstract and subjective evaluations of the decision-makers. Indeed, actions such as "getting a full score in all exams, behaving mannerly, and achieving success in courses" are not observable or measurable and open to individual evaluations. And the fact that the students receive the letter of praise is conditional on "the approval of the officers in charge and approved by the principal" shows that this practice is teacher-centered and authority-based.

It is decided that all boarders at the military schools in the Ottoman Empire shall be given fifty points to show their behaviors and morality at the beginning of each school year (OHN, January 1906, p. 1). A relation of causality was established between the punishments given to students and their moral score. Accordingly; students receiving two birch punishments shall have one point removed. Those receiving two-day imprisonment punishment shall have one point removed. Those receiving one-day abstinence ${ }^{2}$ punishment shall have one point removed. Those receiving one-day fetter ${ }^{3}$ punishment shall have two points removed. Those receiving a punishment of deprivation from leave shall have one point removed, and those repeating the same kind of wrongdoing shall have points removed and the day students receiving warning, admonition, reprimand, and censure punishments shall have points removed in different rates

\footnotetext{
${ }^{2}$ It is the type of punishment applied in the form of not giving one meals.

${ }^{3}$ It is the type of punishment by chaining the feet.
} 


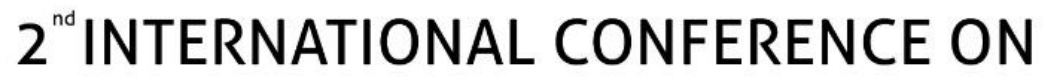 FUTURE OF TEACHING \& EDUCATION
}

Munich,Germany

\author{
6 - 8 December,2019
}

according to whether they are in Istanbul or in other parts of the country (OHN, May 1906, p. 68). The students whose points are all deleted within the relevant year shall be suspended from the school if needed, and their record is deleted (OHN, January 1906, p. 1). In addition, it was decided that the students receiving imprisonment punishment shall have one point removed even if they stay in the prison just for one hour (OHN, January 1906, p. 1), if an imprisonment punishment is converted into "two-day ordinary imprisonment punishment in exchange for each birch punishment ${ }^{4}$ " In the event that the student receiving birch punishment is not suitable for this kind of punishment in medical terms, he shall have points removed according to the calculation of the birch punishment instead of the procedure followed in the imprisonment punishment (OHN, January 1906, p. 2). The students receiving a punishment of deprivation from weekly leave because of unsuccess in lessons shall not have any behavior or moral point off due to this punishment (OHN, January 1906, p. 2) and the students shall have double the points off the amount of those taken off previously "each time" the action is repeated (OHN, January 1906 , p. 2-3). Also, it is laid down as a condition that the students transferred or promoted to another school shall bring the approved copies of their record sheets or completed register with themselves (OHN, January 1906, p. 3). Several provisions have also been laid down for the regulation, keeping, and conservation of the moral record book in a severe way (OHN, January 1906, p. 3-4).

According to the sum of fifty points determined for each year, the students are divided into six degrees of behavior and morality as "excellent, very good, good, below good, average, and weak" (OHN, January 1906, p. 4). These grades to be shown in the behavior and morality section on the diplomas given students by the school (OHN, January 1906, p. 4). This practice can be said to be similar to the "disciplinary punishments" of our day. In this system, students who graduate from the school without any punishment are graded very good, those losing one out of fifty of their points are graded better, those losing less than five points are graded good, those losing less than ten points are graded below good, those losing less than twenty points are graded average, and those with less points are graded weak (OHN, January 1906, p. 4).

Ishak Sunguroglu, a military secondary school graduate, states that the reward system based on praising, liking, and privileges was good because “... it was a well-thought-out and advantageous system that promoted the student to study hard and continue with the school." (Sunguroglu, 1959, p. 58).

\subsection{The Punishment System at Military Secondary Schools}

The instructions issued for students in military secondary schools also define the types of punishments to be imposed on students for their undisciplined behavior within the school (OHN, May 1906, p. 62). In the instructions, the punishments given to students due to offenses, and wrongdoing and because they do not prepare for their lessons are divided into four as

\footnotetext{
${ }^{4}$ The Statute on General Education (Maarif-i Umumiye Nizamnamesi), published in 1869, deems beating with birch allowable, but also specifies the length and type of the birch. This statute recommends to hit the students not with an ordinary birch but with a thin hazel wand that is four spans long in compliance with the laws of Sharia. Nafi Atuf says the purpose of birching the students is to discipline them and the birch must be used as little as possible to prevent the students from seeing it as something usual. See: Nafi Atuf, 1930, p. 109.
}

www@icfte.com 


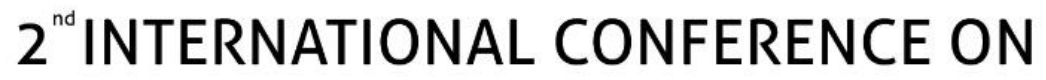 FUTURE OF TEACHING \& EDUCATION
}

Munich,Germany

\author{
6 - 8 December,2019
}

"warning, admonition, reprimand, and censure" according to their degree. Four warnings equal to an admonition, three admonitions to a reprimand, and two reprimands to a censure.

"Discontinuance with the school, disobeying the instruction, having more than one punishments, injuring or attempting to injure someone, disturbing the order in the school, disobeying orders, behaving immorally, skipping the school, disobeying the rules about the lesson equipment, forming harmful habits, and damaging school properties" are the types of offences and wrongdoing that require criminal action. At this point, it can be said that a fourstep punishment mechanism similar to that in the reward system is projected. When the relevant article in the instruction is examined further, it is understood that some rewards are used in return for some punishments.

"Students who receive one of these punishments cannot get out of the it by submitting the letter of reward he has won if the punishment he receives involves an incident. However, if the punishment arises from a daily lesson, the student may get out of it provided that he gives a letter of praising in return for the punishment of the same lesson in the current school year and two letters of praising for each lesson of mid term exam in return for the punishment of the same lesson in the current school year and lesson Those rewards and punishments are recorded in the school register and the records of the students (OHN, May 1906, p. 62)."

When a different article is examined, it is understood that some punishments are exchanged with some leaves. Also, the punishments for heavier crimes are determined to be imprisonment, but it should be noted that imprisonment is a practice defined not only for students but also for teachers. For example, Mehmet Sinasi Efendi, teacher of French at Kocamustafapasa Military Secondary School, was sentenced by the Martial Court to two months imprisonment because he got drunk and exhibited inappropriate behavior in accordance with the Article 98 of the Military Penal Code (BOA. I. HB. 87/40). The relevant article of the instruction for the exchange of rewards and punishments states that:

"Rewards and punishments for boarding military secondary schools and the equivalent students are applied in accordance with these secondary school regulations, but their leave of one week is canceled in exchange for one warning, and their leave of four weeks is canceled in exchange for one admonition. Also, the student is sentenced to one week's imprisonment for one reprimand, and to fifteen days' imprisonment for one censure. Those receiving a suspension or exportation punishment are interrogated before an interrogation board and their statements are presented to the ministry and it is fulfilled according to the order coming from the ministry. The punishment that the students shall receive due to unsuccess at their lessons is to be deprived of weekly leave until it is approved by their teachers that they are successful at their lessons in accordance with the instructions in the fifteenth and sixteenth sections (OHN, May 1906, p. 6263)."

As can be understood from the said article, punishments other than suspension are considered as expected cases of routine disciplinary, but as stated in another article, the instructions and statements of the students who receive suspension punishment are presented to the ministry (OHN, May 1906, p. 63). Another instruction gives the following details about this subject: "Suspension and exportation punishments shall be affixed on the school board's certificate, approved by the general manager and other authorized persons and the related certificate shall be sent to the ministry after the stamped registry bill issued by the school's morality register is 


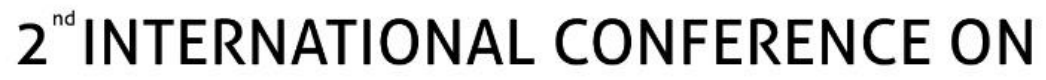 FUTURE OF TEACHING \& EDUCATION
}

Munich,Germany

\author{
6 - 8 December,2019
}

wrapped around the certificate (OHN, March 1899, p. 3)." Therefore, it can be said that the punishments other than suspension are relatively forgivable behaviors; however, when the students commit an offence that requires an exportation punishment, it is seen that the school administration gives various warnings to the student before the exportation. For example, Sehzadebasili Fahreddin Efendi, one of the fifth-grade students at Fatih Military Secondary School, was warned due to his inappropriate behaviors. However, his record was deleted from the school because he insisted on his inappropriate behaviors despite all warnings (BOA. ZB. 349/123).

Regarding the subject, it is requested to collect the rewards and punishments recorded on the list in the annex of the instructions given to the students during the school year, to cancel the lesson rewards corresponding to a lesson punishment, and to transfer the total of the rewards and punishments canceled due to an incident to the new list in the annex of the instruction to be given in the next year (OHN, May 1906, p. 59). In other words, behaviors of the students are not forgotten through records. The relevant article states that there was a section for the degree of morality in the diplomas to be given to the students:

"The suspension punishment stated in the article related to the behavior and morality degrees in the diplomas to be given to the students who have completed their education is determined according to the incident in the morality record of the students during the education period (OHN, May 1906, p. 59-60)."

Another issue about the morality records is about the students transferred from the boarding school to the day school and from the day school to the boarding school. The following provision is included for these students, who take their lesson and morality records together:

"The rewards and punishments of these students are implemented by examining the behavior and morality scores they have in accordance with their decreased or increased record levels in the boarding or day schools they stay. For example, any student who has lost $175^{5}$ points until he is transferred from a boarding school to day school shall be exported if he receives a censure and reprimand in a school in the country and he receives a reprimand and admonition in Istanbul. If a student transferred from a day school to a boarding school has lost his leave from a course in the midterm ${ }^{6}$, he gets out of this punishment that week by giving two letters of praising he has received in that lesson and in that grade (OHN, May 1906, p. 67)."

Although the punishments stated in the instructions do not contain violence, it has been determined that there were, unfortunately, some extreme practices, which can be seen in the document related to a student beaten to death. This document states that Mehmet Efendi, a student at the Kocamustafapasa Military Secondary School, was beaten to death upon the leave given by the assistant principal (BOA. DH. MKT. 1340/50). This shows that there were extreme examples in the implementation of the punishments. It has also been found that the practices of beating students were parallel to a great extent to the findings obtained from the memoirs of the

\footnotetext{
${ }^{5}$ H. 1316 / M. The instruction dated 1898-1899 draws no distinction between Istanbul and the country and states that a student losing 100 points shall be given a censure and reprimand. See: (OHN, 18981899, p. 12).

${ }^{6}$ It is an exam held once every three months in the school year to check whether students study or not.
} 


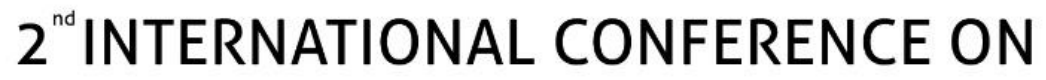 FUTURE OF TEACHING \& EDUCATION}

Munich,Germany

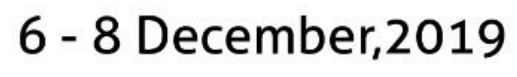

students. It can be understood from the following citation that the students at those educational institutions were kept a close watch on:

"Some days, they carried out searches without prior notice in the morning or the evenings. The students would be lined up in two rows in the garden. One of the two officers would stay with the students in the garden, and the other would keep an eye on them at the balcony in the upstairs so that no one could move. The watch officer would tell the chief janitor to search the students for any gun or any other explosive material, tobacco, cigarette, cigarette case, or playing cards. The school administration was cautious regarding knives, handguns, and mace ${ }^{7}$, etc.. If a student carried any of these materials, he would receive a very harsh punishment. He would be exported from the school if he repeated the same crime. The other punishments were relatively lighter (Sunguroglu, 1959, p. 60).”

It can be seen very clearly in the observations of Ismail Hakki Sunata, a military secondary school graduate, where he says "those who do not listen to the teacher well and cannot answer the teacher's questions will stand up until the end of the lesson (Sunata, 2006, p. 195)." that these schools attached a great important to discipline inside the school as much as they attached to that outside the school. The writers of the memoirs states that even though the boundaries of the punishments were drawn with a legal regulation, the practices and methods implemented were harsh. For example, Celal Esat Arseven, another secondary school graduate, states that "the punishments were really harsh. All kinds of punishments from foot whipping to public beating, from imprisonment in a wardrobe to exporting the student from the school by removing the buttons of his uniform were implemented." (Arseven, 1993, p. 36). Tevfik Saglam, another military secondary school graduate, who details punishments as well as the assessment and evaluation processes, says: "The number of students cheating in exams was not less. Those caught by the teacher would get zero point. The exams were highly serious. Those failing had no right of objection. Students failing in the exams would be harshly scolded by their parents and those parents would never think that their child had been treated unfairly. (Saglam, 2010, p. 33) " Therefore, it can be said that the parents who want their children to be disciplined by any means rationalized the understanding of discipline at the school. Tevfik Saglam explains that beating became a means of training the students:

"At Sogukcesme, the principal means of training was beating. ${ }^{8}$ The officers would always have a birch with themselves. Students committing a crime would be immediately punished by them. Pulling ears, smacking, or birching the student's back were the light types of punishing a student. For harsher punishments, the student would be called into the internal room and birched on his sole or buttocks five to ten times. The intensity would be at the mercy of the one beating the student. The officers would not spare their birch, they got used to it after a while, so did we. Students would not be sentenced to imprisonment at Sogukcesme. There were wardrobes told to have been made for imprisonment punishments but I have never seen anyone imprisoned in them. (Saglam, 2010, p. 28)"

\footnotetext{
${ }^{7}$ A fight instrument made by stitching a pouch of iron and stone pieces put in a strong piece of cloth to a handle made by knitting a few pieces of thick rope half a meter long and dividing the other side of the handle so that it can be hand-gripped and covering this rope thoroughly with a black and thick leather.

${ }^{8}$ Sogukcesme Military Secondary School is one of the first military secondary schools founded in Istanbul. For more information, see: Patoglu, 2018, p. 64-66.
} 


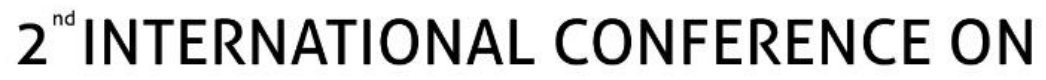 FUTURE OF TEACHING \& EDUCATION
}

Munich,Germany

\author{
6 - 8 December,2019
}

Saying that "... The blonde officer and Adil Efendi were famous for beating the students black and blue. (Sunguroglu, 1959, p. 54)", Sunguroglu gives the following information about the disciplinary processes at the Elazig Military Secondary School:

"There was also a very old senior janitor called Osman Aga, whose room was at the left of the door. This old man always wandered among the students during break time and kept in mind the names of the students who behaved improperly or broke the rules and gave their names to the officers when they entered the classrooms. It meant that something very unpleasant was waiting for those students. They would be beaten and then imprisoned. And the prisons in the school were very strange: they were at the rear side of the head of stairs and next to the administration room and were so narrow that no one could sit down on the ground. Each prison had a gate with a round hole. There were six or seven prisons in the school, in which students were locked after being beaten and waited on foot for hours without food and water. (Sunguroglu, 1959, p. 54)"

As can be understood, the disciplinary practices differed from one school to another but they had a common ground. Sunguroglu recounts that Suleyman Nazif, another secondary school graduate, says in one of his articles: "The school that I went was somewhere that stupefied students and killed their brain. Students would study or learn nothing there, but were trained for endurance against torture. (Sunguroglu, 1959, p. 54)" It can be accepted that such kind of a control method can help decrease crimes, which can be seen in the memoirs of the graduates of military secondary schools who say that there was no one making noise during classes and the students carefully listened to the teacher.

The rules the students must have followed not only outside or inside the school but also after graduation, were determined and published. The instruction "Advises for Students Going to Their Homeland on How to Conduct Themselves" published for this purpose in 1893 reveals that the students were always under control and supervision. This instruction tells the students to be in a certain order even when walking. When these students went somewhere else within the period of time they were in their homeland even though they were not assigned by the school administration, they were asked to have "the high or secondary school principal in regions where there is a high or secondary school; or the supreme soldier or the officer in charge in regions where there is no high or secondary school; or the civilian officers such as the local governor, district governor, or manager" keep the record of their dates of leaving and return on their document of leave (OHN, March 1893, p. 22). In addition, all students were asked to leave their homeland on an appropriate date to be able to be in their school on the fifteenth day of Shawwal, the start date of the school year for military secondary schools and to accommodate at a place that the officer in charge would deem suitable as it was forbidden to stay at an ordinary place when returning to the school. The instruction states that the students breaking the rules would be punished in parallel with their crime and deprived of the right to graduate.

\section{Conclusion}

In the last period of the Ottoman Empire, educational institutions were divided into two groups: "traditional schools" and "modern schools." The military secondary schools, on which this study focuses, is under the group of modern educational institutions. In these institutions, rewards and punishments were determined by several legal regulations different from the 


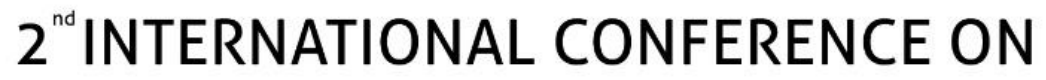 FUTURE OF TEACHING \& EDUCATION
}

Munich,Germany

\author{
6 - 8 December,2019
}

practices in traditional schools. It was not very easy for them to quit the practices they were used to, no matter how different the modern educational institutions were from the traditional institutions. The students receiving education at those schools were also familiar with those practices as much as their teachers were. For example, it is seen that the teachers not using beating as a means of punishment were not taken seriously by the students. The memoirs of Tevfik Saglam, a military secondary school student, who said “... we got used to being beaten. We would laugh at a teacher who did not beat us. (Gunduz, 2010, p. 150)" can help us understand the situation.

Findings reveal that the rewards and punishments that students at military secondary schools received according to their success in lessons and behaviors were built on a four-step structure. It is accepted that the rewards that the students receive due to their success are well-thoughtout and good instruments motivating them to study, continue with the school, and behave properly. On the other hand, it can be thought that the punishments ensured discipline for a certain period of time but traumatized the students.

Apart from the four types of punishment mentioned under the heading "The Punishment System at Military Secondary Schools," in some cases, students are also suspended/exported from the school. For example, it is seen that actions such as not coming to the school for six days within a month, receiving a censure punishment five times within the period of time the student receives education, intentionally injuring someone using any injurious object, lying to the officers or teachers, and disobeying officers or teachers require direct exportation from the school. And there are some students receiving birching punishment for certain crimes such as taking an exam for another student, looking at another student's exam paper or letting someone look on one's paper, cheating verbally or in written or in another way at exams. Those attempting such fraud are punished with public birching in the evening, the deception is made known and they are beaten with a birch fifteen times. However, it can be seen that teachers sometimes lost their control. Mehmet Efendi, one of the students at Kocamustafapasa Military Secondary School, who was "beaten to death" is an example of this.

Students are also given the opportunity to get out of some punishments they receive by providing a letter of reward they win at the school. For example, if the punishment arises from a daily lesson, the student may get out of it provided that he gives one letter of praising in return for the punishment of the same lesson in the current school year. This system, implemented in the same way at some other educational institutions in the Ottoman Empire, can be told to have an advantage of motivating the student to maintain and acquire the good behavior he exhibited; on the other hand, it can be evaluated as a disadvantageous system allowing students to commit a crime relying on the letter of reward he has.

Consequently, it is quite attention-grabbing that some problems occurred in the implementation of the above-mentioned provisions in the legal legislation and some students remember or treat their teachers with whom they have had some bad memories in a respectful and grateful manner despite those problems. Accordingly, Ismet Inonu says: "I gratefully remember Yuzbasi Omer Efendi, my math teacher who failed me for a year. (Inonu, 2009, p. 25)" For another example, Tevfik Saglam writes about his encounter with the officer in charge of the classroom he received education at the military secondary school after a long time: "I encountered Alaeddin Bey in Hasankale during the First World War thirty years after this. I was the Headman in the 


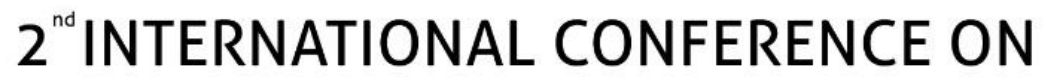 FUTURE OF TEACHING \& EDUCATION
}

\section{Munich,Germany}

\author{
6 - 8 December,2019
}

Medical Company, and he was a section chief in the Quartermaster Branch. We talked about our memories at Sogukcesme. I had difficult days at the school because of him, but now I am not angry at him. I always treated him respectfully (Saglam, 2010, p. 34-35)." Thus, it can be understood from the memoirs of some students that the military secondary school students had an education period with its ups and downs and that they graduated from these institutions with good manners as well as education. However, it is concluded from the information given by the memorial owners that this system left unforgettable and soul-shattering memories in them.

\section{References}

- Arseven, C. E. (1993). Sanat ve Siyaset Hatiralarim, Prepared by Ekrem Isin, Iletisim Yayincilik, Istanbul, Turkey.

- Gunduz, M. (2010). Son Donem Osmanli Egitiminde Disiplin ve Cezalandirma. Dogu Bati Dusunce Dergisi, 13rd Year, Issue 53, Ankara, Turkey.

- Inonu, I. (2009). Hatiralar. Haz. Sabahattin Selek, Bilgi Yayınevi, Ankara, Turkey.

- Nafi Atuf, Türkiye Maarif Tarihi Hakkinda Bir Deneme, Ankara, Muallim Ahmet Halit Kitaphanesi, Birinci Basilis, 1930.

- Osmanl1 Harbiye Nezareti (OHN), Li-ecli's-sila Memleketlerine Giden Sakirdanın Usul-i Hareketlerine Dair Tenbihat, Dersaadet, Harbiye-i Sahane Matbaasi, 29 Şaban 1310/18 Mart 1893.

- Osmanlı Harbiye Nezareti (OHN), Mekatib-i Askeriye-i Şahane Sakirdaninin Tavir ve Ahlak Numrolarina Mahsus Talimatname, Dersaadet, Harbiye-i Sahane Matbaasi, 10 Zilkade 1323/6 January 1906.

- Osmanlı Harbiye Nezareti (OHN), Mekatib-i Askeriye-i Şahanede Müstahdem Bilumum Haceganin Sa'y ve Gayretleri Derecati Meclis-i Maarif-i Askeriyece Ma'lum Olmak ve Mükafat ve Mes'uliyetleri Ona Ibtina Edilmek Üzere Nezaret Kaleminde Tutulmasi Muktezi Görünen Sicilin Suret-i Tertib ve Tanzimine ve Teferruat-i Sairesine Dair Talimatname, Dersaadet, Harbiye-i Sahane Matbaasi, 14 Rebiülevvel 1305/30 November 1887.

- Osmanlı Harbiye Nezareti (OHN), Mekatib-i Rüsstiye-i Askeriye Sakirdanına Mahsus Talimatname, Dersaadet, Harbiye-i Sahane Matbaasi, 1316/1898-1899.

- Osmanlı Harbiye Nezareti (OHN), Mekatib-i Rüsstiye-i Askeriye Sakirdanına Mahsus Talimatname, Dersaadet, Harbiye-i Sahane Matbaasi, 2 Rebiülahir 1324/26 May 1906.

- Osmanlı Harbiye Nezareti (OHN), Umum Mekatib-i Rüsdiye-i Askeriye Me'murinine Mahsus Talimat, Dersaadet, Harbiye-i Sahane Matbaasi, 18 Zilkade 1316/30 March 1899.

- OZBEY, M. (1999). Ikinci Mesrutiyet Surecinde Askerî Orta Ogretim Kurumlarinda Egitim ve Ogretim. Yedinci Askerî Tarih Semineri Bildirileri II, Genelkurmay Askerî Tarih and Strateji Etut Baskanligi Yayinlari, Ankara, Turkey.

- PATOGLU, E. B. (2018). Osmanli Devleti'nde Askeri Rustiyeler. (Unpublished PhD Thesis), Gaziantep University Institute of Social Sciences, Gaziantep, Turkey.

- Saglam, T. (2010). Nasil Okudum. Prepared by Hatemi, H. \& Kazancigil, A., Isaret Yayinlari, 5. Baski, Istanbul, Turkey. 


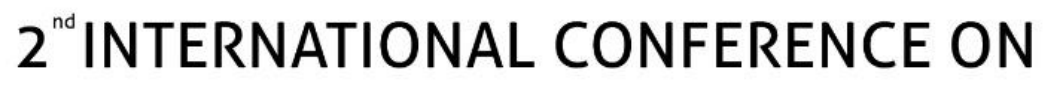 FUTURE OF TEACHING \& EDUCATION}

Munich,Germany

6 - 8 December,2019

- Sunata, I. H. (2006). Istibdattan Mesrutiyete Cocukluktan Genclige. Türkiye Is Bankasi Kültür Yayınlari, Istanbul, Turkey.

- Sunguroglu, I. (1959). Harput Yollarinda. Elazig Kültür ve Tanitma Vakfi Yayinlari, Ikinci Cilt, Istanbul, Turkey.

- The Ottoman Archives of the Prime Ministry, BOA. DH. MKT. 1340/50.

- The Ottoman Archives of the Prime Ministry, BOA. I. HB. 87/40.

- The Ottoman Archives of the Prime Ministry, BOA. ZB. 349/123.

- TDK. (2019). http://sozluk.gov.tr/ 